\title{
Klassernes fortsatte forsvinden
}

\section{Af Stine Thidemann Faber}

Til trods for at intersektionalitetsbegrebet sigter mod at favne fleve forskellige differentieringsprincipper, er der en tendens til, at klasse mere eller mindre overses og/eller forbliver 'undforsket'. Det er nødvendigt på ny at diskutere, på bvilken maide klasse kan og skal analyseres inden for feministisk teori og kønsforskning.

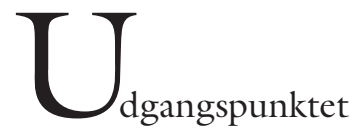

i nærværende artikel er idéen om, at køn og klasse virker sammen og giver ophav til komplekse differentieringsmønstre i nutidige samfund. Et formål med artiklen er således at diskutere og ikke mindst empirisk eksemplificere, hvad der menes, når det gang på gang hævdes, at køn og klasse forstærker, kontrasterer og spiller sammen både med hinanden og med andre former for ulighedsskabende og forskelssættende kategorier.

Hele idéen med et intersektionalitetsperspektiv, og styrken ved dette, er netop tanken om, at kategorier ikke er givne størrelser, som lever separate liv (Martinsson 2005), men at de tværtimod simultant definerer, hvordan menneskers levevilkår formes; at de giver hinanden betydning, og at udfordringen derfor består $\mathrm{i}$ at kunne forklare, hvordan de skabes og forandres $i$ relationen til hinanden. I en artikel med fokus på intersektionalitet kan det derfor synes inkonsekvent, som jeg gør det, at rette 
fokus mod samspillet mellem køn og klasse $u d e n$ at inddrage andre krydsende kategorier. Min intention hermed er imidlertid ikke at nedtone betydningen af disse andre kategorier (fx. race/etnicitet, seksualitet, alder, etc.). I stedet er dette valg begrundet $\mathrm{i}$ et ønske om kompleksitetsreducering; som flere andre også tidligere har været inde på (bl.a. Ludvig 2006; se også Phoenix's artikel i dette nummer) er et af intersektionalitetsperspektivets svagheder, at det i udgangspunktet peger på et uendeligt antal kategorier og måske er der slet og ret grænser for, hvor mange kategorier, man kan jonglere med i en analyse og stadig lykkes? Det må i sidste ende være op til den enkelte forsker at definere og begrunde hvornår, hvor, hvordan og hvorfor nogle kategorier tildeles opmærksomhed frem for andre. I denne artikel er der da også en særlig grund til, at jeg udelukkende vælger at fokusere på samspillet mellem køn og klasse; nemlig det faktum, at dette samspil - paradoksalt nok selv i debatten om intersektionalitet - tilsyneladende har en tendens til at blive 'forbigået'. Et af artiklens hovedformål er således at problematisere den kendsgerning, at international feministisk forskning, på trods af den øgede interesse for intersektionalitet, vedvarende udviser tilbøjelighed til at marginalisere klassekategorien; sandsynligvis fordi spørgsmålet om, hvordan kvinde- og kønsforskere overhovedet kan analysere klasse i dag er omsiggribende og kompliceret. Min forhåbning er, at nærværende artikel kan bidrage til en diskussion, som igen kan gøre klassespørgsmålet vigtigt uden at dette leder til, at andre differentieringsformer af den grund udviskes $\mathrm{i}$ analysen.

\section{MERE Ligestilling - \\ NyE MODSÆTNINGER?}

Hvad enten man hælder til at mene, at køn stadig udgør en væsentlig forskelssættende og ulighedsskabende kategori i nutidige samfund eller ej, er der alt andet lige bred enighed om, at de sidste mange års samfundsmæssige forandringer har været og fortsat er tæt forbundet med en række positive ændringer i relationerne mellem kønnene. Øget adgang til uddannelse, flere jobmuligheder (særligt i det offentlige), udbygning af offentlig børnepasning, udvidede barselsordninger samt mere fleksible arbejdstidsordninger er således eksempler på nogle af de vigtigste strukturelle og institutionelle xndringer, som har bidraget til en øget ligestilling mellem kvinder og mænd (Ellingsæter, Noack \& Rønsen 1997). Behovet for større viden om konsekvenserne af disse store ændringer i relationerne synes imidlertid at trænge sig på.

Det kan måske umiddelbart synes aparte på den måde at problematisere den øgede ligestilling i nutidige samfund. Begrundelsen herfor skal imidlertid søges i det faktum, at de store forandringer i relationerne mellem kønnene har haft vidtrækkende konsekvenser også for sociale relationer i samfundet som et hele; herunder også klasserelationer (Walby 1997. Se endvidere Bradley 1996, Coward 1999 samt McCall 2005). Et af de spørgsmål, som i den forbindelse aktualiseres, er således, hvorvidt mere lighed mellem kønnene også medfører en øget differentiering og en øget ulighed kvinder imellem og mænd imellem. Hvorvidt den øgede ligestilling som sådan er ønskværdig eller positiv er altså ikke stridspunktet; i stedet bør fokus nærmere rettes mod prisen for denne proces og hvem der betaler den: "The price to be paid for a minority of women to achieve equality with men could be greater inequalities for those at the bottom at the ladder" (Bradley 1996, 210).

Walby (1997) beskriver, hvordan ændringerne i relationerne mellem kønnene i dag bedst kan karakteriseres som modsætningsfyldte, komplekse og ikke mindst flertydige frem for entydige. På den ene side bliver flere og flere yngre kvinder bedre uddannede og får attraktive jobs, på den anden side sker der en marginalisering af 
mange - især ældre - kvinder. Samtidig er der, hævder Walby, ligeledes sket en marginalisering af mænd bl.a. fordi de dårligere vilkår og rettigheder, som ofte knytter sig til kvinders arbejde, har skabt nye forudsætninger for og lagt et pres også på mænds arbejde. Walby henviser hermed til, at arbejdsmarkedet for mænd i stigende grad er blevet 'feminiseret' dvs. at mænd i øget grad har fået arbejdsmønstre, som er mere og mere lig kvinders. Med overskriften " $\mathrm{Li}$ fe without Father and Ford" henviser bl.a. McDowell (1991) til, at mænds position på arbejdsmarkedet har ændret sig, ikke mindst fordi behovet for den tidligere mandlige kernearbejder, industriarbejderen, er aftaget. En af konsekvenserne af bruddet med den gamle industrielle samfundsorden er således en større kompleksitet og variation mellem mænd, særlig efter alder og uddannelse.

Uanset hvad er arbejdsmarkedet imidlertid fortsat præget af såvel en horisontal som en vertikal kønsopdeling, med kvinder og det kvindelige placeret nederst. At der er kommet flere kvinder på arbejdsmarkedet, og at flere kvinder bliver bedre uddannede, er imidlertid ikke ensbetydende med hverken at det kvindelige valoriseres eller at alle kvinder bliver ligestillede (se også Hansen 2004). Tværtimod synes udviklingen at gå $\mathrm{i}$ retning af en øget differentiering mellem grupper af kvinder, samtidig med at det kvindelige stadig er underordnet; nu har dette blot også marginaliserende konsekvenser for nogle mænd (Walby 1997). Eksempelvis ses, at mænd, der bryder med arbejdsmarkedets horisontale kønsopdeling og påtager sig kvindearbejde, fx mandlige sygeplejersker, mødes med skepsis og som følge heraf løbende må foretage et mere eller mindre ubevidst identitetsarbejde. Et studie af mandlige sygeplejersker konkluderer således, at mænd i sygeplejen på forskellig vis oplever ambivalens som følge af, at det i samfundet er forbundet med devaluering at udføre kvindearbejde. Dilemmaet for mændene bliver, at de med deres valg af beskæftigelse utilsigtet bryder med det hegemoniske maskulinitetsbillede - mændenes selvforståelse er udpræget maskulin, men de oplever blandt omgivelserne at fremstå som feminine mænd, dvs. umandige. Udtrykt i Bourdieuske termer synes der i høj grad at være tale om, at de mandlige sygeplejersker konstruerer en særegen maskulinitetsform som følge af de muligheder og begrænsninger deres position i det sociale rum giver dem (Bloksgaard \& Faber 2004).

Også Coward (1999) anfører en række argumenter, der på mange måder er i tråd med Walby's ræsonnement, som det er beskrevet ovenfor. Coward går dog et skridt videre og retter en skarp kritik mod kvindeog kønsforskningen, der - som hun ser det - har en tendens til fortsat at tænke relationerne mellem kønnene som en simpel og ensidet magtrelation, hvor mændene pr. definition sidder med de bedste kort (senest har også Bech 2005 hævdet, at der er sket en langt større udligning i kønsmagtforholdet end det fremgår af dagens kvinde/kønsforskning). Coward medgiver, at kvinder stadig på en lang række områder ofte er dårligere stillede end mænd, men samtidig agiterer også hun for, at der ikke længere er tale om noget entydigt billede: "The picture at the moment is much more muddled and uneven. Men are still often the beneficiaries of how gender works in this so-ciety, but now women sometimes are as well" (Coward 1999, 212). Ifølge Coward er ligestillingen mellem kønnene i nutidige samfund endog voldsomt forbedret og megen af den fremgang og de forbedrede vilkår, kvinder har opnået, er i vid udstræk-ning sket på bekostning af mænd fra arbejderklassen:

The combination of feminism and changes in the economy have shattered the easy way in which men could assume that their masculinity entitled them to a superior position (...) Working-class men especially are the scapegoats of a society no longer at ease with masculinity. (Coward 1999, 211-212) 


\section{NÅR KØN OG KLASSE VIRKER SAMMEN}

En af fordelene ved en intersektionel tilgang er, som jeg ser det, bl.a. at den kan skærpe opmærksomheden mod det faktum, at bruddet/splittelsen i klasseoplevelserne er øget fra tidligere og frem til i dag; noget der vel at mærke gælder for begge køn. Når det kommer til studiet af mænd og konsekvenserne af de ændrede samfundsforhold bliver intersektionalitetsbegrebet måske særligt centralt, fordi begrebet netop understreger vigtigheden af at være opmærksom på, både hvordan magt-asymmetrier samvirker, men til tider også hvordan de ophæver hinanden. Mens man i den klassiske feminisme overvejende så kvinder som undertrykt af mænd, kan man i dag se tydelige eksempler på, at køn og klasse spiller sammen på en sådan måde, at det omvendte gør sig gældende. Og måske risikerer særligt mænd fra arbejderklassen at tabe ansigt; i dag ses på forskellig vis, at denne gruppe møder kulturel afstandstagen som en konsekvens af skiftet i den beskæftigelsesmæssige struktur og grundet kvinders indtræden på arbejdsmarkedet. Et empirisk eksempel herpå ses bl.a. i en norsk undersøgelse, hvor der specifikt for mænd viser sig klare elementer af en klasseeffekt fx i forhold til familiedannelsesprocesser. Undersøgelsen konkluderer således, at kvinders øgede autonomi ser ud til at have bidraget til en stærkere finsortering i familiedannelsesprocessen for mænd med relativt kort uddannelse end for mænd med længere uddannelse. Udviklingen synes ganske enkelt at pege i retning af, at en stærkere social selektion fører til, at færre mænd bliver fædre. I stedet ses en øget recirkulering af 'pænt brugte mænd'. I manglen på 'attraktive' partnere vender særligt heteroseksuelle kvinder med høj uddannelse og høje ligestillingsforventninger for fælles forsørgelse, arbejdsdeling og fælles forældreskab sig hellere mod 'brugtmarkedet' end til 'mindre attraktive' mænd, som i denne sammenhæng overvejende betyder mænd med kort uddannelse, traditionelt kønsrol- lemønster og dårlig forsørgerevne (Skrede 2004).

På samme tid peger udviklingen jf. tidligere også i retning af større forskelle mellem grupper af kvinder. Ifølge Walkerdine, Lucey \& Melody (2001) er netop klassespørgsmålet helt centralt i den forbindelse. De skriver således: "It is class, that anachronistic concept of modernity, that more than anything explains the divide between young women entering the labour market today" (Walkerdine, Lucey \& Melody 2001, 4). I forhold til at forstå kvinder i dagens samfund er det forenklet og misvisende at tro, at deres adfærd, holdninger og handlinger blot handler om køn. I så fald ville det ikke kunne forklare, hvorfor kvinder - når man tænker på den vifte af kønsperformances, som rent faktisk er tilgængelige for dem i dag - nu engang foretager de valg, som de hver især gør. Som jeg også var inde på tidligere får nogle kvinder markant bedre levevilkår grundet uddannelse, mens andre kvinder bliver dårligere og dårligere stillede. Der opstår m.a.o. nye forskelle, herunder nye magtforskelle, mellem kvinder indbyrdes, og intersektionalitet fremstår, vil jeg hævde, som et centralt begreb til at gribe også denne udvikling.

I forhold til at se på betydningen af klasseforskelle kvinder imellem er ligestillingspolitik blot ét eksempel på, at reelle forskelle i kvinders livssituation potentielt skaber en rakke forskelle i holdninger og tilsvarende medfører, at forskellige strategier aktualiseres (Skillbrei 2004). I samfundet, som vi kender det i dag, er øget ligestilling et ideal for mange, men samtidig er det vigtigt at være opmærksom på, at ikke alle kvinder nødvendigvis i samme grad har været med i den modernisering af kvinders liv, som har pågået og fortsat pågår (Sørensen 1999). Kontrasten synes at være særlig stor mellem på den ene side middelklassens veluddannede kvinder og på den anden side de lavest uddannede kvinder fra arbejderklassen. De norske forskere Ellingsæter, Noack \& Rønsen (1997) konkluderer således, at 
kvinders forskellige tilgang til uddannelse og arbejde i vid udstrækning influerer på deres syn på og tilslutning til ligestillingspolitikker, og at ligestilling først og fremmest er et ideal for kvinder med høj uddannelse og med gode muligheder for at lykkes på arbejdsmarkedet. Holdningen til ligestilling er desuden stærk afhængig af, hvilken sag og/eller hvilket aspekt, der er tale om. Nogle ligestillingssager har således bred tilslutning ( $\mathrm{fx}$ er der i omtalte norske undersøgelse, uanset uddannelsesniveau, stor enighed blandt de adspurgte kvinder om kvinders ret til uddannelse på lige fod med mænd), mens andre ligestillingsspørgsmål er noget mere kontroversielle (afhængigt af uddannelsesniveau er der fx stor forskel dels på de adspurgte kvinders holdning til kønskvotering og dels på holdningen til kvinders deltagelse på arbejdsmarkedet og normen for 'den gode mor').

Når alle ligestillingssager ikke er lige relevante for alle kvinder, handler det delvist om, at mændene omkring dem som oftest har tilsvarende forskellige vilkår. For nogle kvinder virker det lidet attraktivt at skulle efterstræbe det, mændene har, konkluderer således Skillbrei (2003 \& 2004). Tilsvarende problematik er også Phillips (1987) inde på:

The issues of sexual equality will appeal only to those who are already on their way. The 'ordinary' women, it is said, will have no truck with women's liberation; she cannot luxuriate in moans about male dominance; she has quite enough at her plate as it is. 'Equal pay and opportunities' rings hollow when her husband earns so little. (Phillips 1987, 5)

Hermed henviser Phillips til en pointe, som gennem tiden flere gange har været rejst af forskellige feministiske forskere; nemlig at kampen for ligestilling reelt er et middelklasseprojekt, fordi den jf. tidligere i udgangspunktet vægter de veluddannede kvinders chance for at konkurrere med de veluddannede mænd om de såkaldte 'gode positioner' på arbejdsmarkedet. Ved ten- dentielt at behandle 'kvinder' som en homogen gruppe og usynliggøre ulighed baseret bl.a. på klasse negligeres imidlertid vigtige sociale skillelinjer og ikke mindst interesseforskelle - som en nylig undersøgelse blandt medlemmer af Kvindeligt Arbejderforbund (KAD) (undersøgelsesresultater bl.a. refereret i Ravn 2006) også viser, risikerer ligestilling for de lavest uddannede kvinder ganske enkelt at blive endnu et undertrykkende ideal, de ikke kan leve op til.

Et bredere perspektiv på ligestilling bør i højere grad forholde sig til kvinders forskellighed og uligheder blandt grupper af kvinder. En udfordring fremover består derfor i at udforme politikker, virkemidler og strategier, som kan gøre ligestilling til noget ønskeligt og realiserbart også for kvinder, der ikke har tilgang til magtpositioner i arbejdslivet (Ellingsæter, Noack \& Rønsen 1997, Birkelund 2002, Skillbrei 2003 \& 2004, Ravn 2006). For at kunne gøre dette, vil jeg imidlertid hævde, at det er nødvendigt at opnå større indsigt $\mathrm{i}$, hvordan køn og klasse virker sammen i forhold til at præge kvinders oplevelser, deres opfattelse af dem selv og andre og de muligheder, der er tilgængelige for dem. Tilsvarende argumenterer også Reay (1998):

Women's social-class origins and their contemporary social-class location influence their negotiation of the social world in myriad, complex ways that feminisms have rarely addressed (...) Analyses are increasingly necessary that allow us to theorize the impact that women's differential access to economic, social and cultural resources has on women's lives on a daily basis. Gender, race, sexuality and age only tell us part of the story of difference between women. (Reay 1998, 231, 226)

Ligesom Reay, vil jeg hævde, at vi fortsat mangler viden om, hvordan køn og klasse $i$ dagens samfund virker sammen i forhold til at skabe erfaringer, muligheder og begrænsninger. Begge kategorier er hverken altafgørende eller determinerende pr. defi- 
nition, men foreligger ikke desto mindre som ydre, uundgåelige livsvilkår med betydning for anerkendelse, erfaring, erkendelse, handlemuligheder samt adgang til deltagelse og indflydelse (Hägerström 2004). Såfremt der i analyser af kvinder og mænds liv ikke bliver taget højde for betydningen af klasse, er det umuligt at indfange den stigende kompleksitet og varietet, hvormed livet leves og erfares også i nuværende samfund. Manglende interesse for denne dimension fører slet og ret til en undervurdering af den omstridte betydning køn har, og dermed også til en ufuldkommen forståelse af, hvilke forhold som kan være med til at forandre kønsrelationerne i samfundet (Ellingsæter, Noack \& Rønsen 1997, Reay 1998, Walkerdine, Lucey \& Melody 2001). En diskussion om klasse kan, tænker jeg, bidrage til en radikalisering af feministiske strategier. Problemet er imidlertid, at flertallet $\mathrm{i}$ dag tilsyneladende opfatter klasse som en diffus, usikker og gammeldags kategori.

\section{LAD OS IKKE GLEMME \\ KLASSESPØRGSMÅLET}

Tidligere har køn og klasse primært været analyseret hver for sig, hvilket bl.a. har sine rødder i en efterhånden gammel og velkendt debat - en debat, der udsprang ikke blot af en ideologisk men også en faglig diskussion om, hvilke perspektiver, som bedst var i stand til at indfange de ulighedsskabende mekanismer og processer i samfundet. Mens klasseanalytikerne påpegede, at klasse var vigtigere end køn, holdt feministerne stædigt fast $\mathrm{i}$ det modsatte synspunkt (Birkelund 2002. Se også Baxter \& Western 2001). I dag handler debatten ikke længere om, hvilke af de to kategorier, som er den vigtigste. Efterhånden er der i stedet bred enighed om, at ingen kategori på forhånd kan siges at være væsentligere end andre - at de forskellige kategorier i stedet spiller sammen på konkrete tidspunkter i historien og på konkrete steder og derfor må studeres i relationen til hinanden; heraf intersektionalitetsperspektivet.

De kategorier, der sædvanligvis diskuteres i forhold til intersektionalitet, er som et minimum køn, klasse, race/etnicitet og seksualitet. I remsen indgår klasse som en selvfølge; ofte nævnt tidligere end sent. Alligevel synes klasse fortsat at leve en skyggetilværelse og dermed ledes tankerne tilbage til fordums tider, hvor klassekategorien på forskellig vis havde en tendens til at indtage en marginaliseret position i den feministiske forskning (Martinsson 2005). På mange måder synes den gamle strid om klassebegrebet m.a.o. stadig at lure i baggrunden; i hvert fald hævdes fra flere sider (se fx Walkerdine, Lucey \& Melody 2001, Acker 2003, Gimenez 2005, Knapp 2005 samt McCall 2005), at klassespørgsmålene, når alt kommer til alt, fortsat indtager en marginaliseret og 'uudforsket' position i kvinde- og kønsforskningen. Selv i intersektionalitetsdebatten, der jo ellers har været med til at genetablere fokus på klasseproblemat 'glemme' kategorien klasse, når det kommer til konkrete analyser. Til trods for, at begrebet intersektionalitet ikke kan nævnes endsige forklares uden også at henvise til klassespørgsmålet, er der altså stadig i realiteten forholdsvist få, der retter fokus herimod: "There is much less attention to class than to race in the new literature on intersectionality" (McCall 2003, 21). Også Gimenez (2005) påpeger denne uheldige tendens. Hun skriver direkte:

... Jeg bød intersektionalitetsperspektivet velkomment. Jeg troede, at det skulle bidrage til at øge viden om klasserelationers virkelighed og betydning og om det faktum, at hverken "race-" eller kønsundertrykkelse kan forstås isoleret fra klasse-undertrykkelsens virkelighed. Mine forventninger blev imidlertid ikke indfriet: placeringen af klasse i slutningen af "race" /køn/klasse-trilogien afspejler dets relative vægt indenfor intersektionalitetsperspektivet; klasse er "kædens svage led. (Gimenez 2005, 59; min oversættelse) 
Samme problematik gør sig for så vidt gældende i den skandinaviske debat. I det omfang intersektionalitetsbegrebet på nuværende tidspunkt har vundet indpas i Skandinavien, har det også her primært været i relation til studier af $\mathrm{k} ø \mathrm{n}$ og etnicitet (i Danmark se fx Staunæs 2003 og Mørck 1998).

\section{KLASSEBEGREBETS PROBLEMATISKE FORHISTORIE}

I slutningen af 1960 'erne og op gennem 1970'erne argumenterede feminister for, at klasseanalysen - hvad enten denne var marxistisk eller weberiansk inspireret - enten totalt ignorerede kvinder eller baserede sig på antagelsen om, at kvinders klasseposition kunne bestemmes på baggrund af deres ægtefælle. Klasseanalysen blev således bl.a. kritiseret for ikke at tage højde for betydningen af en lang række samfundsmæssige ændringer, herunder kvinders øgede tilgang til arbejdsmarkedet, og mens mange kritikere argumenterede for, at såvel kvinder som mænd burde inkluderes i klasseanalysen, fastholdt en lang række repræsentanter for det konventionelle syn, at det ikke var nødvendigt at trække kvinderne ind $\mathrm{i}$ klasseanalysen, så længe de ikke var lige så betydningsfulde for familiens klassesituation som mænd. Jeg skal ikke her gå yderligere ind $\mathrm{i}$ alle elementerne fra diskussionen fra dengang (for en uddybende beskrivelse henvises i stedet til Crompton 1998, Baxter \& Western 2001 samt Acker 2003, 2005), men blot fremhæve, at spørgsmålet om, hvordan man bedst kombinerer et klasseog kønsperspektiv er kendt for at have forårsaget vanskelige diskussioner såvel indenfor sociologien som i international kvindeog kønsforskning.

Ifølge Acker (2003) gxlder, at mange feminister vedvarende op gennem 1990'erne og frem til i dag - i det omfang de overhovedet refererer til klasse - skildrer, diskuterer og refererer til klassespørgsmål uden at forholde sig til begrebets genealogi og dermed også uden at forholde sig til den debat om begrebet, som tidligere feminister var med til at rejse. Acker finder dette problematisk og argumenterer for, at en af grundene til, at intersektionalitetsperspektivet tilsyneladende har svært ved at håndtere klassekategorien netop er, at hele den 'gamle' klassediskussion er forblevet uløst:

Attempts to reconceptualise class to include women more adequately were not completely successful and interest in class theory among feminist declined. When scholars in the U.S. began to call for an understanding of the intersections between class, gender and race/ ethnicity, only the reformulated idea of class were available. (Acker 2003, 49)

Selvom feministisk teori gennem tiderne ikke helt har glemt klasse har der, ifølge Acker, længe ikke været nogen nævneværdig interesse $\mathrm{i}$ at reformulere begrebet og på ny diskutere samt afklare, på hvilken måde klasse kan og skal analyseres indenfor feministisk teori og kønsforskning. For Acker er det indlysende, at diskussionen omkring intersektionalitetsbegrebet tillige må indbefatte at tage hånd om denne problematik. Hun suppleres på dette punkt af Knapp (2005), der på tilsvarende vis argumenterer for, at dagens køns- og kvindeforskere, inden de ukritisk optager intersektionalitet som begreb, nødvendigvis må se nærmere på og forholde sig til den 'bagage', der følger med begrebet:

"More specifically "reclaiming baggage" would translate into: Let's work through the critical theoretical traditions again, but starting from present-day problematic and on the basis of insights gained from former controversies”. (Knapp 2005, 261)

Knapp argumenterer altså ligesom Acker for, at der er behov for nye feministiske måder at skrive om klasse på, og at intersektionalitetsforskningen i den forbindelse står 
overfor en stor udfordring; ikke mindst i forhold til at afklare og integrere klassespørgsmålet.

\section{EN VANSKELIG KATEGORI}

Ligeledes i forhold til konkrete undersøgelser, der har fokus på klassespørgsmålet, ses en interessant udvikling. Det viser sig nemlig, at det ikke kun er på det teoretiske plan, at klasserne er forsvundet; også empirisk er klassespørgsmålet over en årrække blevet mere og mere vanskeligt at indfange.

At det ikke er ubetinget let at studere klasse, har jeg selv stiftet bekendtskab med via egen forskning. I forbindelse med indsamling af empiri til min igangværende ph.d.-afhandling, har jeg bl.a. interviewet tyve kvinder med vidt forskellig økonomisk og uddannelsesmæssig baggrund bl.a. med henblik på at afdække på hvilken måde køn tænkes, praktiseres og konstrueres afhængig af social position. I denne proces har jeg således selv konstateret, at det hverken er ligetil eller enkelt at få folk til at snakke om, hvordan klasseulighed og kulturelle forskelle skabes. Mit udgangspunkt har været et forsøg på at afdække grundlaget for informanternes klassificering af sig selv og andre. Ligesom Skilbrei (2005) bygger jeg således $\mathrm{i}$ vid udstrækning på, hvordan de interviewede kvinder italesætter forskelle for "at lære mere om det distinktionsarbejde, som er en del af at konstruere og acceptere klasseforskelle" (Skilbrei 2005, 55). Jeg har forsøgt at snakke om klasse på flere forskellige måder med mine informanter (jf. også Skilbrei 2003 \& 2005). Jeg har bl.a. spurgt ind til forholdet til kollegaer på arbejdspladsen (fx "Hvem føler du samhørighed med? Hvem føler du ikke samhørighed med?) samt informanternes venskabskreds (fx Kan du beskrive din vennekreds? Kan du komme i tanker om nogle venner, som du er 'vokset fra'. Hvorfor/hvordan? Er der nogen typer af mennesker, som du i udgangspunktet vil have svært ved at blive venner med?). Herudover har jeg mere konkret prøvet at stille spørgsmål såsom "Er der nogle mennesker, som er specielt indflydelsesrige og magtfulde $\mathrm{i}$ det danske samfund? Er det rimeligt, at det forholder sig sådan, vil du sige?” og "Er der nogen i samfundet, som du mener, ikke får den anerkendelse, de fortjener?" Svarene på mine spørgsmål har langt fra altid været fyldige og længe undrede jeg mig over, hvor svært det egentlig var at få informanterne til at snakke om de her ting. Når de kvinder, jeg har interviewet, som oftest har værget sig ved at snakke om ulighed og forskellighed, handler dette, ifølge Sayer (2005), bl.a. om, at "class is an embarrassing and unsettling subject. In many social situations it would be considered insensitive to refer to class, particularly to the class of someone to whom we are talking or who is within earshot" (Sayer 2005, 1).

En anden grund til, at det er svært at spørge ind til klasseforskelle er sandsynligvis også, at der er tale om processer, som i dag er mere eller mindre usynlige for folk selv. At indfange klasse handler derfor i lige så høj grad om at finde ud af, hvordan klasse i nuværende samfund overhovedet manifesterer sig det levede liv. Ja, måske er det faktisk netop heri den første og potentielt største udfordring viser sig - nemlig at forstå "the role class plays in relation to gender today, when almost everything that traditionally defined class has broken down" (Walkerdine, Lucey \& Melody 2001, 1). I søgen efter dette gxlder det samtidig som forsker om at være opmærksom på, at klasse i dag ikke nødvendigvis giver sig til kende $\mathrm{i}$ form af accept og identifikation, men måske i lige så høj grad kommer til udtryk via modstand og disidentifikation, men det skal jeg komme nærmere ind på nedenfor.

Ifølge Anthias (2004) er det, hvis intersektionalitetsbegrebet skal kunne anvendes som et frugtbart analytisk perspektiv, nødvendigt at skille forståelsen af sociale positioner (dvs. de konkrete positioner den enkelte er givet qua dets sociale ressourcer; økonomiske såvel som kulturelle) fra social 
positionering (dvs. måden hvorpå den enkelte forstår, artikulerer og interagerer med disse positioner $\mathrm{fx}$ ved at stille krav, udfordre og definere). Jeg mener, at Anthias har fat i noget væsentligt her. Opfattelser af køn, race/etnicitet, seksualitet, etc. samvirker med forestillinger om klasse og får afgørende betydning for, hvilken subjektposition, der kan antages. Afhængig af en række 'baggrundsfaktorer' har alle således forskellig tilgang til subjektpositionerne. Kategorierne brydes ofte i subjektiveringsprocesserne og den enkelte kan til en vis grad vælge enten at omfavne eller gøre modstand mod at blive positioneret. Der er m.a.o. ikke nødvendigvis en sammenhæng mellem objektive positioner og individers subjektive forståelse af, hvem de i virkeligheden er, hvilket Skeggs (1997) også levendegør i Formations of Class and Gender. Heri illustrerer Skeggs overbevisende, hvordan klasse er bestandigt nærværende i unge britiske arbejderklassekvinders liv - kvinderne føler imidlertid ikke nogen samhørighed med arbejderklassen (disidentifikation) og kæmper i stedet via smag og livsstil for at signalere et tilhørsforhold til middel- klassen (for uddybning, se Christensen \& Siims bidrag i dette nummer).

Skeggs hævder, at usynliggørelsen af klasse representerer et historisk stadium, hvor middelklassens identitet garanteres, og at den senere tids manglen på interesse for klassebegrebet, såvel blandt samfundsvidenskabelige som feministiske forskere, skal betragtes som et direkte resultat af, at klasseskel i dag er institutionaliserede, legitimerede, accepterede og veletablerede i samfundet. Specifikt i forhold til kvinde- og kønsforskningen problematiserer Skeggs det manglende fokus på relationen mellem køn og klasse ved helt konkret at spørge: "Is it that for those who now get to write and represent feminist (and) cultural theory class is not experienced or felt as immediately as gender? It may not be recognized as a problem for those who have the priviledge to ignore it" (Skeggs 1997, 6). Selv kan jeg ikke rigtigt slippe dette sidste spørgsmål.

\section{AFsLUTTENDE KOMMENTARER}

Jeg mener ikke, at man skal undervurdere intersektionalitetsbegrebets anvendelighed indenfor dagens kvinde- og kønsforskning. En vigtig styrke ved begrebet er, som jeg også løbende har argumenteret for i artiklen, at det skærper forskerens opmærksomhed mod det faktum, at kategorier skabes og forandres i relationen til hinanden; at køn og klasse, fordi de spiller sammen, i nogle tilfælde forstærker hinanden $\mathrm{fx}$ for økonomisk og uddannelsesmæssigt privilegerede mænd samt for økonomisk og uddannelsesmæssigt underprivilegerede (oftest ufaglærte) kvinder, mens de i andre tilfælde udligner, måske endda ophæver, hinanden fx for økonomisk og uddannelsesmæssigt privilegerede kvinder samt økonomisk og uddannelsesmæssigt underprivilegerede (oftest ufaglærte) mænd (se også Ravn 2006).

Samtidig med at jeg finder begrebet nyttigt, bl.a. fordi det øger fokus mod de ændrede køns- og klasserelationer i dagens samfund, tilslutter jeg mig, at begrebet skal udfoldes, da det ellers er i fare for at forblive en slags mantra, som kan rables af $i$ alle sammenhænge. Såfremt begrebet vinder indpas 'blot' som et paraplybegreb, der signalerer en interesse for "mere end bare køn” (Carbin \& Tornhill 2004), kan det være godt det samme. Remsen 'køn, klasse, race/etnicitet, etc.' er besnærende uforpligtende at lire af, og det er sandsynligvis en af forklaringerne på, hvorfor den så forholdsvist uproblematisk og hurtigt er blevet en tilsyneladende naturlig og selvfølgelig del af den feministiske diskurs. Som også Fornäs (2005) påpeger, er vi imidlertid kommet til et punkt, hvor intersektionalitetsbegrebet på forskellig vis har behov for at blive preciseret, eventuelt differentieret i forskellige principielle varianter, operationaliseret og sat i arbejde i specifikke undersøgelser. I 
den forbindelse mener jeg, som det fremgår af nærværende artikel, at kvinde- og kønsforskningen står overfor en udfordring; ikke mindst i forhold til at diskutere og afklare på hvilken måde klasse kan og skal analyseres indenfor feministisk teori og kønsforskning.

\section{LITTERATUR}

- Acker, Joan (2003): "The Continuing Necessity of 'Class' in Feminist Thinking". I Gesellschaftstheorie und feministische kritik: Achsen der Differenz. Westfälischen Dampfboot, Münster.

- Acker, Joan (2005) Class questions: feminist answers. Rowman \& Littlefield Pub. Inc. New York. - Anthias, Floya (2004) "Social stratification and social inequality: Models of intersectionality and identity". I Devine et al. (2004): Rethinking Class. Culture, Identities \& Lifestyle. Palcrave Macmillan, Hampshire.

- Baxter, Janeen \& Mark Western (2001) Reconfigurations of class and gender. Stanford University Press, Stanford.

- Bech, Henning (2005) Kvinder og mend. Hans Reitzels Forlag, København.

- Birkelund, Gunn Elisabeth (2002) "Kjønn og makt i arbeidslivet - klasseanalytiske perspektiv". I Ellingsæter \& Solheim (red.) (2002): Den usynlige hånd. Kjonnsmakt og moderne arbeidsliv. Gyldendal akademisk, Oslo.

- Bloksgaard, Lotte \& Stine Brock Faber (2004) Kon på arbejde - en kvalitativ undersøgelse af mandlige sygeplejershers og kvindelige politibetjentes arbejdsliv. Aalborg Universitetsforlag, Aalborg.

- Bradley, Harriet (1996) Fractured identities: changing patterns of inequality. Polity Press, Cambridge.

. Carbin Maria \& Sofie Tornhill (2004) "Intersektionalitet - ett oanvändbart begrepp?”. I Kvinnovetenskaplig Tidskrift, vol. 3, 2004.

- Coward, Rosalind (1999) Sacred Cows. Is Feminism Relevant to the New Millennium. HarperCollins Publishers, London.

- Crompton, Rosemary (1998) Class and Stratification. An Introduction to current debates. Polity Press, Cambridge.

- Ellingsæter, Anne Lise, Noack, Turid \& Marit Rønsen (1997) "Social ulikhet blant kvinner: polarisering, utjevning eller status quo? I Tidsskrift for Samfunnsforskning, nr. 1, 1997.
· Fornäs, Johan (2005) "Röster som gjorde skillnad. Korsande identifikationer i folkhemmets populärmusik". I Kvinnovetenskaplig Tidsskrift, no. 23, 2005 .

. Gimenez (2005) "Teori eller mantra? En kritisk granskning av intersektionalitetsperspektivet". I Socialistisk Debatt, no. 1, 2005.

. Hägerström, Jeanette (2004) Vi och dom och alla dom andra andra på Komvux - Etnicitet, genus och klass i samspel, Lund Dissertations in Sociology 59, Sociologiske institutionens publikationer.

- Hansen, Lise Lotte (2004) Ligestillingspolitiske problemer - og mulige losninger. Kon, magt es forandring $i$ LO og UNISON, Ph.d. afhandling, Institut for Samfundsvidenskab \& Erhvervsøkonomi, RUC.

- Knapp, Gudrun-Axeli (2005) "Race, Class, Gender - Reclaiming Baggage in Fast Travelling Theories". I European Journal of Women's Studies, vol. 12 , no. 3, 2005.

- Ludvig, Alice (2006: "Differences Between Women? Intersecting Voices in a Female Narrative". I European Journal of Women's Studies, vol. 13, no. 3, 2006.

- Martinsson, Lena (2005) “Är klass en kategori bland andra?". I de los Reyes \& Martinsson (red.) (2005): Olikhetens paradigm - intersektionella perspektiv på o (jäm) likhetsskapande. Studentlitteratur, Göteborg.

- McDowell, Linda (1991) "Life without Father and Ford: The New Gender Order of PostFordism". I Transactions of the Institute of British Geographers, New series, vol. 16, no. 4, 1991.

- McCall, Leslie (2005) "Managing the complexity of intersectionality". I Signs: Journal of Women in culture and Society, vol. 30, no. 3, 2005.

- Mørck, Yvonne (1998) Bindestregsdanskere: fortallinger om køn, generationer og etnicitet. Forlaget Sociologi, København.

- Phillips, Anne (1987) "Divided Loyalties - dilemmas of sex and class". Virago Press, London. - Ravn, Anna-Birte (2006) "Køn og klasse. Om nytten af begrebet intersektionalitet". I Borchorst \& Christensen (red.) (2006) Konsrefleksioner-om magt og mangfoldighed. Aalborg Universitetsforlag, Aalborg.

- Reay, Diana (1998) Class Works. Mothers' Involvement in Their Children's Primary Schooling. Taylor \& Francis Ltd, London.

- Sayer, Andrew (2005) The moral significance of class. Cambridge University Press, Cambridge.

- Skeggs, Beverley (1997) Formations of Class and Gender. Becoming Respectable. SAGE Publications, London.

- Skilbrei, May-Len (2003) Dette er jo bare et hus- 
morjobb. Ufaglerte kvinner $i$ arbeidslivet. Rapport 17/03. NOVA, Oslo.

. Skilbrei, May-Len (2004) "Mine, dine og våre saker: Likestillingspolitikk for viderekomne." I Kvinneforskning, no. 3, 2004.

. Skilbrei, May-Len (2005) "Klasse, kjønn og etnicitet som erfaringer". I Sosiologi i dag, vol. 35, No. 4, 2005.

. Skrede, Kari (2004) "Familiepolitikkens grense ved 'likestilling light'?". I Ellingsæter \& Arnlaug (red.) (2004): Velferdsstaten og familien. Utfordringer og dilemmaer. Gyldendal Norsk Akademisk A/S, Oslo.

- Staunæs, Dorthe (2004) Køn, etnicitet og skoleliv. Samfundslitteratur, København.

- Sørensen, Bjørg Aase (1999) "Ansvar og individuering”. I Birkelund, Broch-Due \& Nilsen (red.) (1999): Ansvar og protest. Kjønn, klasse og utdanning i senmoderniteten. Sosiologisk Institutt, Universitetet i Bergen, Bergen.

- Walby, Sylvia (1997) Gender Transformations.

Routhledge, London.

- Walkerdine, Valerie, Helen Lucey \& June Melody (2001) Growing up girl. Psychosocial explorations of gender and class. Palgrave, Hampshire.

\section{SUMMARY}

The notion of intersectionality has become important in order to understand the condition of the subject in a society that among other factors are characterized by changing gender relations. The notion relates itself to a society in which categories such as gender, class, ethnicity, age, sexual preferences, etc. interact with each other in novel and a more fluid and fluctuant way than earlier. Even though, internationally, feminist research has begun to focus on the intersection between different categories, it seems that the attention directed towards class is still minimized; class somehow seems to continue to live in obscurity, which is why a reflection of a distant past comes to mind as the class category by various means has a history of marginalisation within the feminist agenda. The article thus emphasizes the need to develop new feminist ways of thinking and writing about class.

Stine Thidemann Faber, ph.d.-stipendiat, Institut for Sociologi, Socialt Arbejde og Organisation, Aalborg Universitet 